\title{
クローズドサイクル海洋温度差発電システム の動特性モデルに関する実験的検討
}

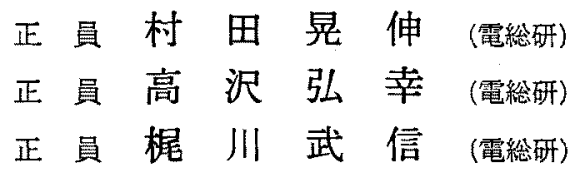

\section{1.はじめに}

自然エネルギー利用システムの特徽の一つとして, 入力が変動しやすいということが挙げられる。海洋温 度差発電システムの場合に流, 海の状況に芯じて取水 温度や取水量が変動する。海洋温度差発電システムは 利用温度差が小さいので，取水温度の変動はシステム 性能に大きな影響を及ほす。しかし, 海水温度の変動 は十分ゆっくりしているので, 取水温度変動の影響を 評価するのにシステムの過渡的振舞を考虑する必要は ない。一方，洋上設置形発電システムを対象とした検 討(1) 亿よると, 取水量变動が最大となる波浪の周期は 約 $10 \mathrm{~s}$, 変動幅は波高を $2 \sim 3 \mathrm{~m}$ とすると平均取水量 の $20 \sim 30 \%$ と見䅪られている。取水量変動は速く, 变動幅す大きいのでシステムの過渡的な応答を検討す る必要がある。

これまで海洋温度差発電システムの動特性モデルが 幾つか提出されているが(2)(3)，乙れらのモデルでは熱 交換器を取水量変動によらない一定の伝熱性能をすっ た集中定数系として取扱っている。実際には，熱交換 器の水侧伝熱性能は熱交換器内の水の流速に依存し, 流速の变動が大きいときには水側熱伝達率も大きく変 動する。また，流速の変動䚮速いのて熱交換器は分布 定数系として取扱う必要がある。従って，従来のモデ ルは小振幅の取水量変動に対しては有効であ万うが, 海洋場で想定される大振幅の速い変動に対しては不十 分だと考えられる。

Experimental Study of Transient Modeling of Closed Cycle Otec Power System. By Akinobu Murata, Member, Hiroyuki Takazawa, Member \& Takenobu Kajikawa, Member (Electrotechnical Laboratory).

村田晃伸：正員，雷子拉衍総合研究所

高沢弘幸 : 正員, 理子技衡総合研究所

梶川武住：正員，電子技衔総合研究所

扈学論 B, 107 巻 3 号, 昭 62

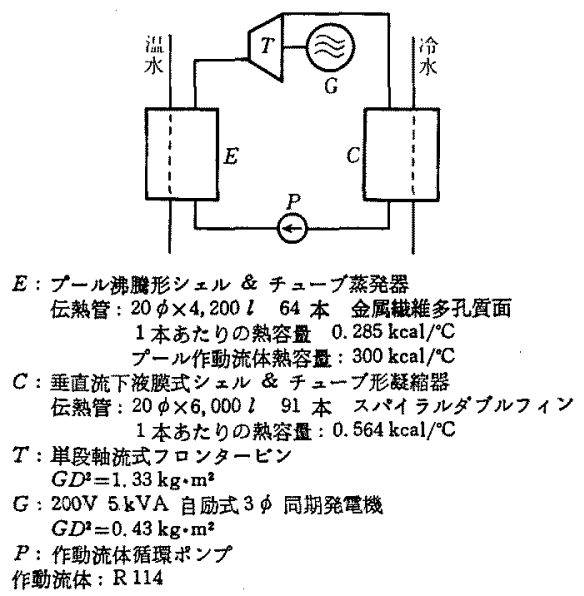

図 1 OTEC III シミュレータ

Fig. 1. OTEC III simulator.

本論文は電総研の OTEC III シミュレータを用い て，取水量変動に対する熱交撸器性能变化を含めた， より詳しい海洋温度差発電システムの動特性モデルに 関して実験的検討を行ったすのである。実験に用いた OTEC III シミュレータは，プール沸騰式シェル\&チ ニーブ形蒸発器, 液膜流下式シェル\&チューブ形凝 縮器, フロンタービン, 三相同期発電機, 抵抗負荷, ポンプおよびそのはかの関連機器からなる。詳細は他

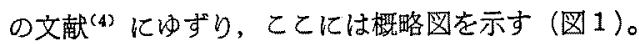
システム全体の動特性の検討任先立って主要要素機器 の動特性を検討し，それらの個々のモデルを連系させ て全体システムのモデルを作成した。そして実験結果 との比較によってモデルを検証した。

\section{2. 熱交換器の動特性}

$\langle 2 \cdot 1\rangle$ 検討事項熱交換器の動特性を調べる際 
の檢討事項を挙げると以下のようになる。

(1) 伝熱管壁内の過渡的な熱伝導の扱い方。

(2) 伝熱管内流速加変動するときの水側熱佉達率の 技い方。

(3) 作動流体側熱伝達率の报い方。

海洋温度差登電のような低熱落差発電では, 出力に 比べて熱交換器の姏理熱量加大きい。従って, 熱交換 器内の熱の流れを詳しく模擬する必要があることから (1)を検討事愐とした。流量变動時の管内熱伝達に関し ては，流れが首流の場合について検討した例 が，乱流の場合の报い方はよくわかっていない。熱交 換器内の流れは通常乱流であるので，(2)ついて明ら かにして抢く必要がある。(3についても同様である。

〈2・2〉実験方法 実験にはステップ忘答法を用 い, 熱交換器の入口水温およで水流量を弁操作で急变 したときの出口水温，作動流体各部の温度，作動流体 蒸気、死，作動流体循環量を測定した。温度の測定には サーミス夕，圧力の測定には水晶圧力計，水流量の測 定には電磁流量㖕を用いた。作動流体の蒸気側の流量 は, 蒸気側と液側の流量バランスの变化が凝縮器内の 液たまりの作動流体量の変化として観察されるととを 利用して, 凝縮器内液た专りの作陲流体量変化速度上 液側作動流体流量との差をよって求めた。液たまりの 作動流体の量は液面高さとしてポンンシォメータで, 液側の作動流体流量はタービンメータで測定した。

\section{〈2.3〉伝熱管壁内の過渡的な熱伝導}

（1）端面の温度が緩やかに变勤する壁の中の一次 元熱伝導の近以解 板の車面の温度は初め一定で あるが， $t=0$ を境化楥やか比変動しだするのとする (図2)。乙の場合の方程式は

$$
\partial T / \partial t=\chi \partial^{2} T / \partial x^{2}
$$

初期市よじ境界条件は

$$
\begin{aligned}
& T(t, 0)=T_{w i}(t) \\
& T(t, D)=T_{w 0}(t)
\end{aligned}
$$

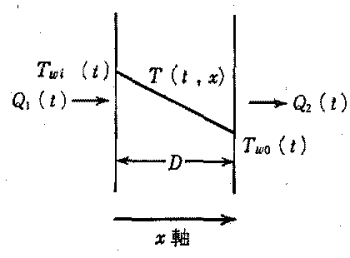

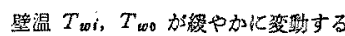

図 2 薄い壁の内の一次元熱伝導

Fig. 2. One dimensional heat convection through a thin wall.

$$
\left.T(0, x)=T_{w i}(0)+\left(T_{w i}(0)-T_{w 0}(0)\right) x / D\right)
$$

ここで，T $(t, x)$ : 温度分布， $\chi:$ 温度伝導

率, $D$ : 板厚, $T_{w \mathrm{r}}(t), T_{w 0}(t)$ : 端面の温度 $z=x / D, \tau=t \chi \mid D^{2}$ 之极いて(1)の解を書く之

$$
\begin{aligned}
T(\tau, z)= & (1-z) T_{w i}(\tau)+z T_{w 0}(\tau) \\
& -\frac{2}{\pi} \sum_{n=1}^{\infty} \frac{\sin n \pi z}{n} \int_{0}^{\tau} e^{-n^{3} \pi^{2}\left(\tau-\tau^{\prime}\right)} \\
& \times\left\{\frac{d T_{w i}}{d \tau}\left(\tau^{\prime}\right)-(-1)^{n} \frac{d T_{w 0}}{d \tau}\left(\tau^{\prime}\right)\right\} d \tau^{\prime}
\end{aligned}
$$

(2)式中 $e^{-n^{2} \pi^{2}(\tau-\tau \prime)}\left(0 \leqq \tau^{\prime} \leqq \tau, n=1,2 \ldots\right)$ は極めて 速く減衰するので, $d T_{w i} / d \tau, d T_{w 0} / d \tau$ の変化が緩や かであれば皘分を次のように近似的に部算できる。

(2)式中の積分 $\fallingdotseq\left\{\frac{d T_{w i}}{d \tau}(\tau)-(-1)^{n} \frac{d T_{w 0}}{d \tau}(\tau)\right\}$

$$
\begin{aligned}
& \times \int_{0}^{\tau} e^{-n^{2} \pi^{2}\left(\tau-\tau^{\prime}\right)} d \tau^{\prime} \\
& \times \int_{0}^{\tau} e^{-n^{2} \pi^{2}\left(\tau-\tau^{\prime}\right)} d \tau^{\prime} \\
& \doteqdot \int_{-\infty}^{\tau} e^{-n^{2} \pi^{2}(\tau-\tau)} d \tau^{\prime}=\frac{1}{n^{2} \pi^{2}}
\end{aligned}
$$

（3）式を(2)式に代入すると

$$
\begin{aligned}
T(\tau, z) & \fallingdotseq(1-z) T_{w i}(\tau)+z T_{w 0}(\tau) \\
& -\frac{2}{\pi^{3}} \frac{d T_{w i}}{d \tau}(\tau) \sum_{n=1}^{\infty} \frac{\sin n \pi z}{n^{3}} \\
& +\frac{2}{\pi^{3}} \frac{d T_{w 0}}{d \tau}(\tau) \sum_{n=1}^{\infty} \frac{(-1)^{n} \sin n \pi z}{n^{3}}
\end{aligned}
$$

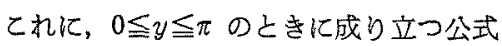

$$
\begin{aligned}
& \sum_{n=1}^{\infty} \frac{\sin n y}{n^{3}}=\frac{y}{12}(\pi-y)(2 \pi-y) \\
& \sum_{n=1}^{\infty} \frac{(-1)^{n} \sin n y}{n^{3}}=-\frac{y}{12}\left(\pi^{2}-y^{2}\right)
\end{aligned}
$$

を用いると

$$
\begin{aligned}
T(\tau, z) \doteqdot & (1-z) T_{w i}(z)+z T_{w 0}(z) \\
& -\frac{1}{6} \frac{d T_{w i}}{d \tau}(\tau) z(1-z)(2-z) \\
& -\frac{1}{6} \frac{d T_{w 0}}{d \tau}(\tau) z\left(1-z^{2}\right) \ldots \ldots
\end{aligned}
$$

を得る。時刻 $t$ 亿おいて端面 $z=0$ 加ら壁に流入する 熱流束を $Q_{1}(t), x=D$ に扔いて壁から流出する熱流 束を $Q_{2}(t)$ とすると

$$
\begin{aligned}
& Q_{1}=-c_{p} \chi(\partial T / d x)_{x=0} \\
& Q_{2}=-c_{p} \chi(\partial T / \partial x)_{x=D} \\
& \text { ただし, } c_{p}: \text { 壁の比熱 }
\end{aligned}
$$


であるから（4)式と $z=x / D, \tau=t \chi / D^{2} よ り$

$$
\left.\begin{array}{l}
Q_{1}=\frac{T_{w i}-T_{w 0}}{R_{w}}+\frac{C_{w}}{3} \frac{d T_{w i}}{d t}+\frac{C_{w}}{6} \frac{d T_{w 0}}{d t} \\
Q_{2}=\frac{T_{w i}-T_{w 0}}{R_{w}}-\frac{C_{w}}{6} \frac{d T_{w i}}{d t}-\frac{C_{w}}{3} \frac{d T_{w 0}}{d t}
\end{array}\right\}
$$

ここで, $R_{w}$ : 壁の単位面積あたりの熱抵抗,

$C_{w}:$ 単位面積あたりの熱容量 を得る。

（2）伝熱管壁内の過渡的熱伝導の近似解 伝熱 管は円管であるが直径に比べて肉厚が小さいので，そ の中の伝熱を(1)項で扱った一次元熱伝導とみなすて とができる。そこで(5)式を採用する。ただし，熱抵 抗および熱容量の計算には管の平均直径に基づく面皘 を用いた。

〈2・4〉過渡状態における水側および作動流体側熱

\section{伝達率}

（1）定常状態の熱伝達率 流速む入口温度も一 定である場合，円管内の乱流熱伝達の熱伝達率は次式 で与えられる(6)。

$$
\left.\begin{array}{l}
\mathrm{Nu}=0.023 \operatorname{Re}^{0.8} \operatorname{Pr}^{0.4} \\
h=\mathrm{Nu} d / \lambda
\end{array}\right\}
$$$$
\text { ここで, } \mathrm{Nu} \text { ：又セルト数, } \mathrm{Re}: \text { レイノルズ }
$$

数, $\operatorname{Pr}:$ プラントル数, $d:$ 伝熱管内径, $h$ :

熱伝達率, $\lambda:$ 水の熱伝導率

作動流体側熱伝達率は熱流束の関数である。例えば。 蒸発器に用以られている金属䋐維焼結面では実験的に

$$
h \propto q_{E^{n}} \quad(n=0.2 \sim 0.7)
$$

$q_{E}:$ 熱流束

の関係が得られている(7)。

（2）変動がある場合の検討方針 温度による物 性値の変化を無視すると, 入口温度が変動しても流速 が一定であれば (6)式によって水側熱伝達率が計算さ れる。流速が変化する場合の水側熱伝達率拈よび作動 流体側熱伝達率の検討は表 1 の手順で行う。次節で述 べる方法によれば熱交換器内における水側から作動流 体側への過渡的な熱の流れや伝熱管内平均水温の変化 を知るととができる。更に入口温度変動の場合には, 前述のとおり水側熱伝達率が既知なので伝熱管壁温度 の変化を求め作動流体側熱伝達率や過熱度に関する検 討を行うととができる。一方, 作動流体側からみれ ば, 水側の入口温度変動む流量変動むとむに伝熱管外 壁温度の変動之みなされるから, 入口温度変動実験か ら得られる作動流体側熱伝達率や過熱度関する結果 は流量変動時にあ妥当であると考えられる。従って， 過渡的熱収支と合せて伝熱管壁温度の变化を求め, “流
表 1 熱伝達率に関する実験的検討の手順 Table 1, Flow chart for the experimental study on heat transfer coefficients.
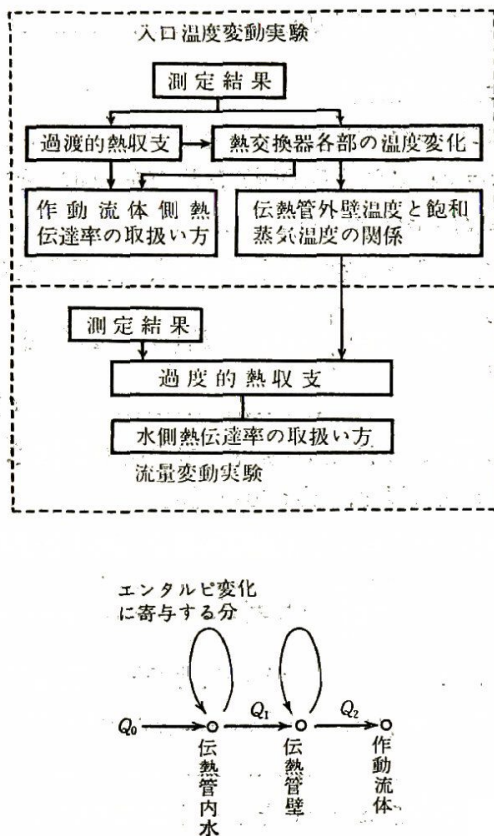

見加けの水側処理㷫量 $Q_{0}$ は水のエンタルヒ 一変化分と $Q_{1}$ の和であり， $Q_{1}$ は伝熱管壁 のエンタルピー変化と $Q_{2}$.の和である。

目 3 熱交換器内の過渡的な熱収支

Fig. 3. Transient heat balance in a heat exchanger.

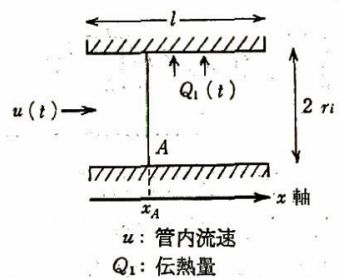

図 4 、伝熱管内の伝熱

Fig. 4. Heat transfer in a tube.

量変動時の水側熱伝達率の変化を検討するととができ る。

（3） 入力変動時の熱交換器の過渡的な熱収支 入力変動時の熱交換器内での熱の流れを図 3 亿示す。 水加ら管壁任伝わる熱量 $Q_{1}$ は管壁加ら作動流体伝 わる熱量 $Q_{2}$ 之管壁温度の変化槣与する熱量の和 である。この三者の関係は（5)式で表される。Q1 計算は次のようにして行う。図4 亿示すような1本 刀伝熱管を考える。管軸方向に $x$ 軸をとり，入口を 
$x=0$, 出口を $x=l$ とする。時刻 $t=t_{1}$ で伝熱管に入 b， $t=t_{2}$ で管を出る面状の流体要素 $A$ を考える。時 刻 $t\left(t_{1} \leqq t \leqq t_{2}\right)$ に $A$ 少いる位置を $x_{A}(t)$ とすると

$$
x_{A}(t)=\int_{t_{1}}^{t} u(\tau) d \tau
$$

$u(\tau)$ : 管内流速

伝熱管に沿った熱流束分布を $q(t, x)$ とし, 時刻 $t$, 位籄 $x=x_{A}$ に拈bる局所的熱流束を $q_{A}(t)$ とする上

$$
q_{A}(t)=q\left(t, x_{A}(t)\right)
$$

$q_{A}$ を $t_{1}$ から $t_{2}$ まで積分すると次式が得られる。

$$
\int_{t_{1}}^{t_{2}} q_{A}(\tau) d \tau=\frac{1}{2} r_{i} c_{p} \rho\left\{T_{i}\left(t_{1}\right)-T_{0}\left(t_{2}\right)\right\}
$$

$r_{i}$ : 伝熱管内半径, $c_{p}, \rho:$ 水の比熱亡密度,

$T_{i}$ : 入口温度, $T_{0}$ : 出口温度

一方, 時刻 $t$ における全処理熱量を $Q_{1}(t)$ とすると

$$
Q_{1}(t)=2 \pi r_{i} \int_{0}^{l} q(t, x) d x
$$

$t_{1} \leqq t \leqq t_{2}$ におりる $q(t, x)$ の変化を線形近似すると

$$
q(t, x)=q\left(t_{1}, x\right)+\partial q\left(t_{1}, x\right) / d t \cdot\left(t-t_{1}\right)
$$

(12)式において $x=x_{A}$ とし両辺に $2 \pi r_{i} u(t)$ を措け て， $t_{1}$ 加ら $t_{2}$ まで積分すると次式が得られる。

$$
\begin{aligned}
& \int_{t_{1}}^{t_{2}} q_{A}(\tau) u(\tau) d \tau=m Q_{1}\left(t_{1}\right)+(1-m) Q_{1}\left(t_{2}\right) \\
& m=\frac{1}{t_{2}-t_{1}} \int_{t_{1}}^{t_{2}} M\left(x_{A}(\tau)\right) d \tau \\
& M(x)=\int_{0}^{x} \frac{\partial q}{\partial t}\left(t_{1}, x\right) d x / \int_{0}^{l} \frac{\partial q}{\partial t}\left(t_{1}, x\right) d x
\end{aligned}
$$

(13)式中のmは熱流束分布に依存し，一般には時間の 関数である。しかし特別な場合，例えば壁温と流速が 一定の条件で入口水温が変動する場合には定数とな る。ここではむっと粗い近似で伝熱管を集中定数と みなし $\partial q / \partial t$ が $x$ によらないよ近似すると

$$
\begin{aligned}
& M(x)=x / l \\
& m=\frac{1}{l\left(t_{2}-t_{1}\right)} \int_{t_{1}}^{t_{2}} x_{A}(\tau) d \tau
\end{aligned}
$$

(16)式からわかるように，mの値は流速の測定值から 決めることができる。流速が一定の場合汇は $m$ の值仗 0.5 になる。流速が変動する場合导 $t_{1} \leqq t \leqq t_{2}$ におけ る変動量が，それはど大きくないときには 0.5 に近い 徂をとる。

$u ， T_{i}, T_{0}$ は測定できる量なので(10)式の右辺は湘
定值から定めることができる。従って，適当な初期条 件を与えると(10)式から $q_{A}(t)$ が定められる。すると (13)式の左边它定まり適当な初期条件のもとで(13)式 から $Q_{1}(t)$ を定めることができる。初期条件には，ス テップ状の変動を加える前の状態におりる值を用いる としができる。なお，

$$
Q_{0}(t)=c_{p} \rho \pi r_{i}^{2} u(t)\left\{T_{i}(t)-T_{0}(t)\right\}
$$

で計算される $Q_{0}$ を見掛けの水側观理熱量亡呼ぶよ，

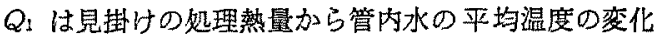
に寄与する熱量を差し引いたすのに等しい。徒って, 平均管内水温の変化量は次式で与えられる。

$$
\Delta T_{m}=\int \frac{Q_{0}-Q_{1}}{C_{W T}} d \tau
$$

ただし， $\Delta T_{m}$ : 平均水温変化量, $C_{W T}$ : 管内 水熱容量

(4) 実験結果と検討 蒸発器に関する結果を示 す。図5 (a) は流量 (総流量 $90 \mathrm{~m}^{3} / \mathrm{h}$, 管内流速 1.62 $\mathrm{m} / \mathrm{s}$ ) を一定に保って入口温度を变哩させたときの各 部の温度変化を表している。実線で表した入口温度 $T_{i}$, 出口温度 $T_{0}$, プール作動流体液温 $T_{F E}$, 作動流 体飽和蒸気温度 $T_{\varepsilon}$ は测定から得られたものであり， 破線で表した平均管内水温 $T_{m}$, 平均外壁温度 $T_{w 0}$ は過渡的熱取支から計算したものである。このときの 熱収支を(b)図に示した。同㘡中 $Q_{0} \sim Q_{2}$ の意味は既

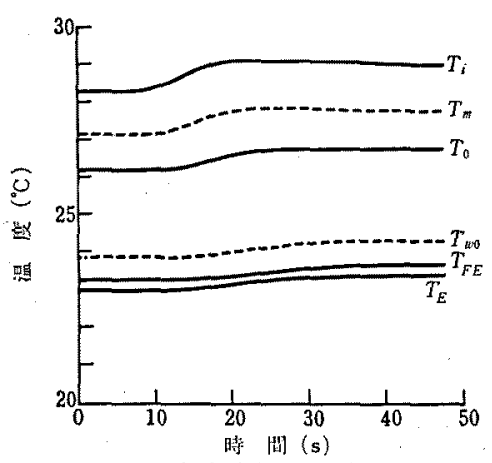

(a) 各部の湝度率化

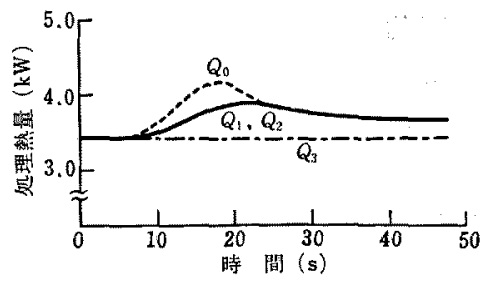

（b）事渡的大然取支

図 5 入口温度変動に対する蒸発器の過渡応答

Fig. 5. Transient response of evaporator to inlet water temperature variation. 
述のよおりである。Q 気に伝えられる熱量で次式により求めた。

$Q_{3}=G_{F}\left\{H_{f o}\left(T_{E}\right)-H_{f l}\left(T_{F C}\right)\right\}$

$G_{F}$ : 作動流体䛻環量, $H_{f o}(T)$ : 温度 $T$ 飞お

ける作動流体蒸気のエンタルピー, $H_{f l}(T)$ :

温度Tに抢りる作動流体液のエンタルピー,

$T_{F C}$ : 蒸発器入口におりる作動流体液温

$Q_{2}$ は $Q_{3}$ 亡蒸発器プール作動流体液温変化儿奇与す る熱量の和である。図 5（a）から，平均管外壁温度之 飽和蒸気温度の差は变動中ほぽ一定であることがわか る。また (b)図からは変動中 $Q_{3}$ がほぽ一定であるこ とがわかる。この 2 点加ら作動流体蒸気化対する管外 熱伝達率 $\beta$ は変動中ほぼ一定とみなせることがわか る。

$$
\beta=Q_{3} / S_{0}\left(T_{w 0}-T_{E}\right)
$$

$S_{0}:$ 伝熱管外壁面積

㘡 5 のケースでは $\beta=14 \mathrm{~kW} /{ }^{\circ} \mathrm{Cm}^{2}$ である。また

$$
\begin{aligned}
& \gamma=\left(Q_{2}-Q_{3}\right) / S_{0}\left(\Delta T_{w 0}-\Delta T_{F E}\right) \\
& \Delta T_{w 0}, \Delta T_{F E}: T_{w 0}, T_{F E} \text { の変動量 }
\end{aligned}
$$

と扔いて，入口温度の変動幅を変えた幾つかの実験の 結果について子を求めてみると，ほほ一定值 $12 \mathrm{~kW} /$ ${ }^{\circ} \mathrm{Cm}^{2}$ をとることがわかった。 $Q_{2}-Q_{3}$ はプール作動流 体液温の変化倍与する熱量であり，rは液温変化に 関する管外熱伝達率である。一方，管壁の熱容量はプ 一ル作動流体の熱容量に比へてて分小さく，壁温変化 は熱収支にはあまり影響しない。それで図5（b）の $Q_{1}$ とQ2 にははとんど差がない。

次に，流速が変化するときの水側熱伝達率について 検討を行った。過渡的熱収支加ら求めた $Q_{0}$ と $Q_{1}$ を 用いると，平均管内水温 $T_{m}$ が(18)式を使って計算 される。一方，管外壁温度と飽和蒸気温度の差が一定 であるという入口の温度変動実験から得られた結果が 流速变動時にも当てはまるとすると，管外壁温度を次 式加求めることができる。

$$
T_{w 0}=T_{E}+\left(T_{w 0}-T_{E}\right)_{\text {初期圤热 }}
$$

乙の $T_{w 0}$ 上 $Q_{1}$ を既知量として $(5)$ 式を解く之管内 壁温度 $T_{w i}$ と $Q_{2}$ を定めることができる。以上の值 を用いると水㑡熱伝達率 $\alpha_{H}$ は次式で計算される。

$$
\begin{aligned}
& \alpha_{H}=Q_{1} / S_{i}\left(T_{m}-T_{w i}\right) \\
& S_{i}: \text { 伝熱管内面積 }
\end{aligned}
$$

入口温度 $\left(T_{i}=28.3^{\circ} \mathrm{C}\right)$ を一定に保って流量を变動さ せた実験から得られた $\alpha_{H}$ の変化と，その之きの管内 流速 $u$ の変化を図 6 に示す。比較のために同図には (6)式上 $u$ の瞬時値から求められる準定常的な水側熱 伝達率 $\alpha_{H C O L}$ を破線で示した。同図加ら $\alpha_{H C O L}$ か⿱

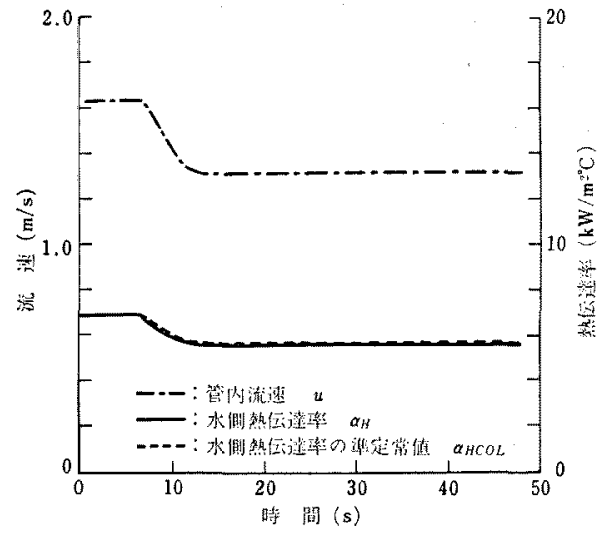

実駼から得られた水侧熱伝達率の推定值を，(9)式を用い

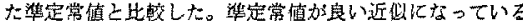
ことがかかる。

図 6 流速が変化するときの水側熱伝達率の变化

Fig. 6. Water-side heat transfer coefficient variation due to changing water flow rate.

$\alpha_{H}$ の良い近似になっていることがわかる。

（5）熱伝達率についてのまとめ

（a）作動流体側熱伝達率 管外壁加ら作動流 体側任伝えられる熱量 $Q_{2}$ は, 作動流体蒸気仁伝 えられる熱量 $Q_{3}$ とプール作動流体液温変化比寄 与する熱量 $Q_{2}{ }^{\prime}$ の和である。Q $Q_{3}$ と $Q_{2}{ }^{\prime}$ は

$$
\left.\begin{array}{l}
Q_{3}=S_{0} \beta\left(T_{w 0}-T_{E}\right) \\
Q_{2}{ }^{\prime}=S_{0} \gamma\left(\Delta T_{w 0}-\Delta T_{F E}\right)
\end{array}\right\}
$$

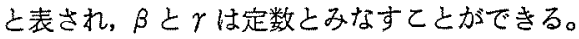

（b）水側熱伝详率（6）式で与えられる。流 速が変化する場合にも(6)式之流速の瞬時值から 求めた準定常的な值を用いる。

$\langle 2 \cdot 5\rangle$ 熱交換器の動特性方程式

(1) 前提

(1) 熱交換器は分布定数系しして扱う。

(2) 伝熱管ごとの違いは考虑せず単管性能で代表 させる。

(3) 伝熱管における熱の流机は軸に垂直な万向だ けに起こる。

(4) 熱伝達率の扱い方枯〈2・4〉節 ( 5 ) 項に述へた とおり。

(5) 液相と気相の作動流体循環量は等しい。

OTEC III シミュレータには，凝縮器内の液たまり 液面高さを一定に保つような制御が施されているため (5)がほぼ成立つ。

(2) 蒸発器 蒸発器の方程式を表 2 亿示す。表 中, (A)式の第 1 項は伝熱管に流入する熱, 第 2 項は 管内水加ら管内壁に伝わる熱，第 3 項は管内水温の变 


\section{表 2 蒸発器の過渡モデル}

Table 2. Transient evaporator model.

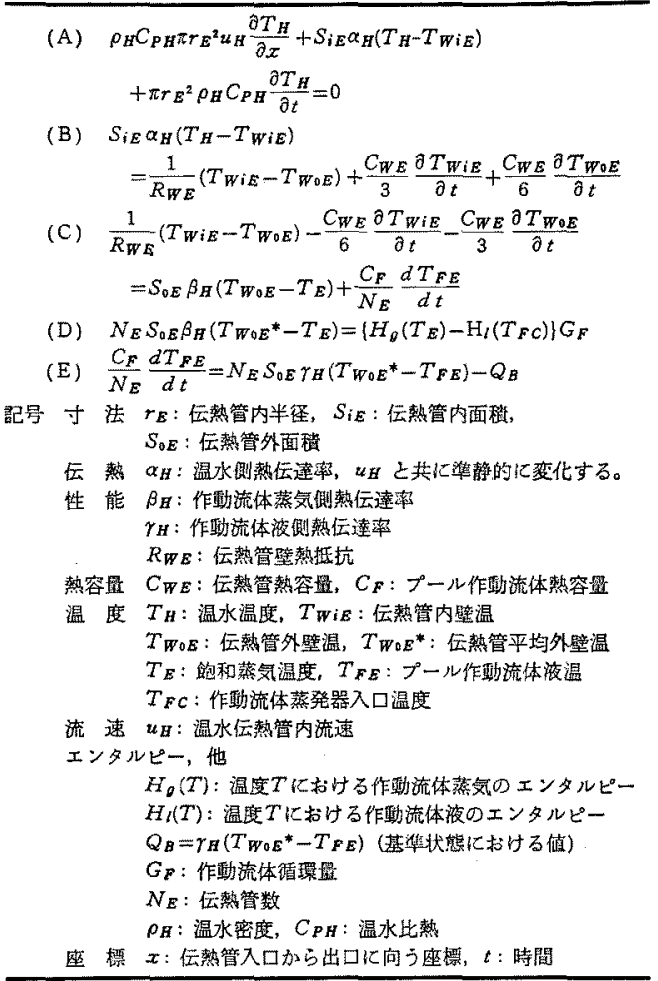

化に寄与する熱を表し，全体として管内水の熱収支を 表している。（B）式は管内水之管内壁の間，（C)式は 管外壁と作動流体の間の熱のやりとりを表しており， 各々（5)式に基づいている。(D)式は作動流体則でみ た熱の授受を表している。(E)式はプール作動流体液 温変化に関する式である。（E)式中の $Q_{B}$ は基準状態 におけるプール作動流体液への伝熱量を表す。ステッ プ状変動の場合は基準状態として恋動印加前の状態を とる。

（3）㠜縮器凝縮器の方程式を表 3 亿示す。同 表中，(A)〜(D) 式の意味は蒸発器の場合とほとんど 同じなので異なる点についてだけ述へる。(C)式にお いて作動流体液膜の熱容量を省略した。凝縮液膜の熱 容量の大きさを見積ったとてろ管壁の熱容量に比べて 十分小さかったからである。(D)式の最後の項を付け 加えたのは次の理由による。凝縮器内部を満たしてい る作動流体蒸気の量は压力と共に変化する。变化した 分は伝熱管上に凝縮し潜熱を放出する。凝縮器におい ては，タービンからの排熱と上記の熱の和が姏理熱量 となる。(D)式の最後の項は蒸気たまり内蒸気の㠜螬 による熱放出を模擬している。
表 3 凝縮器の過渡モデル

Table 3. Transient condenser model.

(A) $\rho_{L} C_{P L} \pi r c^{2} u_{L} \frac{\partial T_{L}}{\partial x}+S_{i c} \alpha_{L}\left(T_{L}-T_{W i C}\right.$

$$
+\pi r C^{2} \rho_{L} C_{P L} \frac{\partial T_{L}}{\partial t}=0
$$

(B) $S_{i c} \alpha_{L}\left(T_{L}-T_{W i c}\right.$ $=\frac{1}{R_{W C}}\left(T_{W i C}-T_{W O C}\right)+\frac{C_{W C}}{3} \frac{\partial T_{W i C}}{\partial t}+\frac{C_{W C}}{6} \frac{\partial T_{W B C}}{\partial t}$

(C) $S_{0 C} \beta_{L}\left(T_{W O C}-T_{C}\right)$

$$
=\frac{1}{R_{W C}}\left(T_{W i C}-T_{W O C}\right)-\frac{C_{W C}}{6} \frac{\partial T_{W i C}}{\partial t}-\frac{C_{W C}}{3} \frac{\partial T_{W O C}}{\partial t}
$$

(D) $N_{C} S_{0 C} \beta_{L}\left(T_{C}-T_{W P O}{ }^{*}\right)$

$$
=\left\{H_{D}\left(T_{S}\right)-H_{l}\left(T_{F C}\right)\right\} G_{F}+\xi c \frac{d T_{C}}{d t}
$$

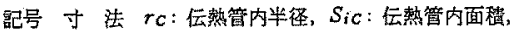
$S_{\mathrm{a}} \mathrm{C}:$ 伝熱管外面䆏

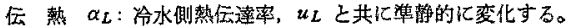

性 能 $\hat{\beta}_{L}$ : 作勘流体側熱伝達率

$\xi c:$ 颣樎器蒸気たまり蒸気㘈縮俰数

$R_{W C}:$ 伝熱管壁熱措抗

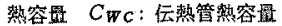

酒 度 $T_{L}$ : 冷水温应, $\quad T_{W i C}$ : 伝熱䇴内壁温

$T_{W 0}$ ：伝等管外譬温， $T_{W 0} C^{*}$ ：伝整管平均外壁温 $T_{C}$ : 飽和蒸気温底, $T_{s}$ : タービン出口蒸気温度

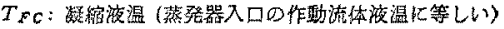
流 速 $u_{L}:$ 冷水伝熱管内流速

エンタルピー, 他

$H_{g}(T)$ : 温度Tに找的る作㲜流体蒸気のエンタルピー

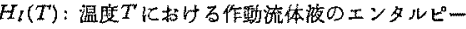

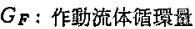

$N_{C}:$ 任熱管数 $\rho_{L}$ : 冷水密度, $C_{P L}:$ 冷水此熱

邀 標 $x$ : 伝熱管入口加ら出口に向亏座想， $t:$ 䠌間

\section{3. タービン・発電機の動特性}

$\langle 3 \cdot 1\rangle$ 運動方程式とモデル化のための仮定 タービン・発電機の回転運動の方程式は

$I d \omega / d t=T Q_{m}-T Q_{e}$

$I:$ 軸慣性モーメント， $\omega:$ 軸の角速度, $T Q_{n}$ ：

タービン軸駆動トルク，TQt: 発電機目荷卜

ルク

$T Q_{m}$ はタービン軸出力 $P_{m}$ を $\omega$ で割ったすのに等し い。タービン出入口に杍ける作動流体蒸気の熱落差を $\Delta i_{T}$, 作動流体循環量老 $G_{F}$ とすると， $P_{m}$ は

$$
P_{m}=A G_{F} \Delta i_{T}
$$

$A$ : 熱の仕事当量

定常の場合，タービン入口における蒸気圧上温度，夕 一ビン出口の蒸気圧およびタービン回転数を与えれば $\Delta i T$ が定まる。また $G_{F}$ 专次式で計算される。

$$
G_{F}=\varphi_{N} A_{N} \sqrt{\frac{2 g \kappa}{\kappa-1} \rho_{i} p_{i}\left(\frac{p_{0}}{p_{i}}\right)^{2 / \kappa}-\left(\frac{p_{0}}{p_{i}}\right)^{(\kappa+1) / \kappa}}
$$

$\varphi_{N}$ : ノズル提失係数, $A_{N}$ ノズル面積， $\kappa$ : 比熱比, $\rho_{i}$ : タービン入口の蒸気密度, $p_{i}$, $p_{0}:$ 入口坊よび出口压, $g:$ 重力加速度 
同様に真荷トルク $T Q e$ と電気出力 $P e$ の間には次の 関係がある。

$$
T Q_{e}=P_{e} / \eta_{\theta} \omega
$$

\section{$\eta_{0}:$ 発電機效率}

発電機は自励式なので定常時の出力は $\omega$ 之負荷抵抗值 の大きさだけで決まる。

熱交换器の入力変换化伴う近力変動や負荷変動があ る場合を扱うために次の仮定をおく。

(1) 変動の場合に李 $T Q_{m}, T Q_{t}$ は定常の場合之同 じ式を用いて準定常的に計算される。

(2) 変動の場合にも $G_{f}$ は(26)式を用いて準定常的 に計算される。

(3) 運動方程式は(25)式である。 仮定(1)〜3に対する一つの検証として負荷変動実験を 行った。

\section{$\langle 3 \cdot 2\rangle$ 負荷变動実験}

（1）実験方法 熱交換器の入力は一定に保って おく。負荷抵抗の大きさをステップ状に変えて発電機 端子電圧の変化を調へる。電生はトランスデューサで 测定した。

（2）結果と梌討 温水入口温度 $28.3^{\circ} \mathrm{C}$, 温水流 量 $90 \mathrm{~m}^{3} / \mathrm{h}$, 冷水入口温度 $6.3^{\circ} \mathrm{C}$, 冷水流量 $90 \mathrm{~m}^{3} / \mathrm{h}$, 負荷抵抗值の変動率 $+16 \%$ の場合についてモデル計 算值と测定值を比べた結果を図 7 に示す。計算値は測 定值を良く再現しており，この場合の仮定(1)〜(3)の罗 当性を示している。

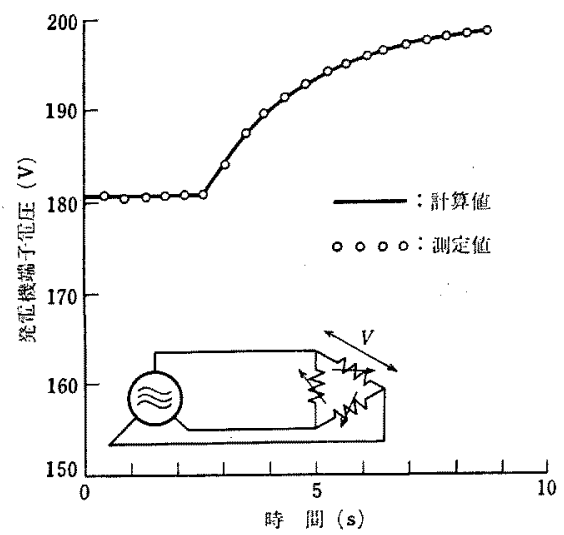

タービン軸歌動トルクと負荷トルクに関する準定常な仮定 を用いなモテルと実測做を比較した。

図 7 負荷抵抗をステップ状に切り換え たときの発電機端子電圧の変化

Fig. 7. Generator output voltage variation due to a step-wise load change.

\section{4. 全体システムの動特性}

〈4・1〉動特性モデル これまで検討してきた要 素機器の動特性の式を連立させれ代，全体の動特性モ デルになる。ただし，〈2・5〉節（1）項でも述へたたお り作動流体の蒸気側と液側の循環量は常に等しいとす る。数值計算にあたって表 2 , 表 3 中の偏徽分方程式 はルジャンドル関数を用いたガレルキン法によって常 微分方程式に変換された ${ }^{(8)}$ 。モデルを検証するために シミュレータ全体の動特性実験を行った。

〈4.2〉 モデルの検証 本実験では装置の都合上 ステップ状のほうが大きく速い変動を作りやすいため ステップ状の流量変動比対しモデルを検証した。実 海洋場では周期的な変動が予想されるから, どのよう なステップ状変動を用いればよいかは一つの閣題であ るが，次のように考えることができる。ある時点より 前ではゼ口, それ以後は周期 $4 T_{0}$, 振幅 $a$ の 3 角波之 いう変動は図 8 に示すとおり变動幅 $a$, 変動時間 $T_{0}$ のステップ状変動の重称合せとるるととができる。系 が線形ならば応答に関して重稀せ原理が成り立つ。 非線形な系でも一定範围の変動に対しては線形近似す るととができるから，後者のステップ状変動は前者の 繰返し変動に対応すると考えてよいであろう。実海洋 場では周期 $10 \mathrm{~s}$ 程度の流量变動が想定されるから， $T_{0}=3 \mathrm{~s}$ 程度のステップ状变動に対してモデルを検証 すればよい。実験では温水および泠水の入口温度と負 荷抵抗は一定保保与，温水流量之冷水流量江個別に テップ状変動を与えて，熱交撸器内蒸気圧や発電機端 子電圧の変動をみた。温水入口温度 $28.3^{\circ} \mathrm{C}$, 冷水入 口温度 $6.5^{\circ} \mathrm{C}$, 温水流量 $91 \mathrm{~m}^{3} / \mathrm{h}$, 冷水流量 $90 \mathrm{~m}^{3} / \mathrm{h}$ の状態から温水流量を变動させたときの発電機端子電

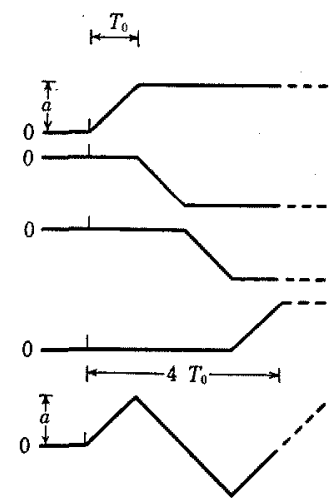

図 8 ステップ状変動と繰返し変動の対応

Fig. 8. Correspondence of a step-wise change and a repetitive change. 


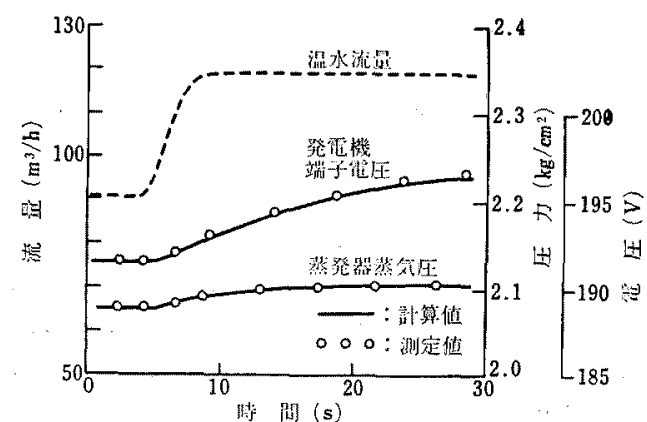

(a) 鼬水流些变倒

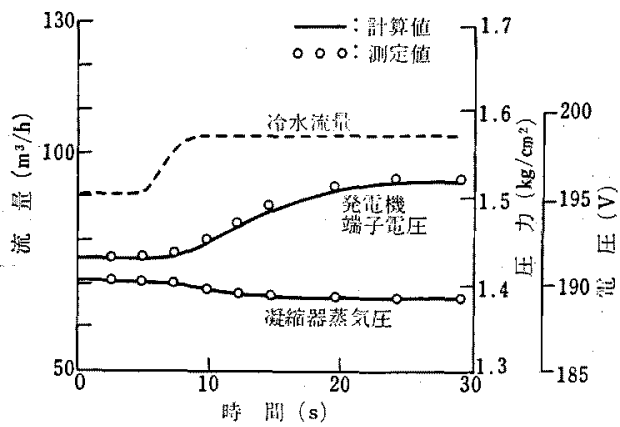

(b) 椧水流罢変㲜

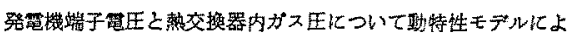
る計算值と実测檤を比較した。。

図 9 流量変動に対する応答に関する実験 結果とシミュレーション結果の比較

Fig. 9. Comparison of experimental and simulation results of transient response to water flow rate change.

圧と蒸発器蒸気仕の変化を図 9（a) に示す。また，同 じ基準状態から泠水流翼を変動させたときの発電機端 子電圧と凝縮器蒸気圧の変化を同図 (b) k示す。流量 の変動時閻 Toは 3〜 $4 \mathrm{~s}$ である。奏線で表されてい るモデル計算值と○印で表されている测定倠は良く一 致しており，モデルの罗当性が検証さ机た。なお，モ デルに必要な作動流体㑡熱伝達率などの檤は基準状態 の測定値から求めたすのを用いた。

\section{5. 終 りに}

海洋温度差発電システムの動特性モデルに関して OTEC III シミュレータを用いた実験的検討を行った 結果, 海洋場で想定される程度の流量変動に対するシ ステムの動特性について次のことが明らかになった。

（1） 入力変動時の熱交換器の水側熱伝達率の变化 は準定常的に扱うことができる。

（2） 入力变動時 0 作動流体側熱伝達率は基準状態 における值に等しく変動中一定とみなせる。

（3）タービンの軸駆動トルク，発電機の負荷トル ク实準定常的に扱うことができる。

要素機器の動特性に基づいて作成した全体システム の動特性モデルを，シミュレータの動特性実験によっ て検証し実海域で予想される程度の流量変動に対して モデルが有効であることが示された。

最後に，本研究に対し支援と理解をいただいた当所 小山健一エネルギー部長ならびに杉浦 蜸次長に謝意 を表します。本研究は，サンシャイン計画総合研究の 中で行われたあのである。

(昭和 61 年 5 月 22 日受付, 同 61 年 9 月 22 日再受付)

\section{文献}

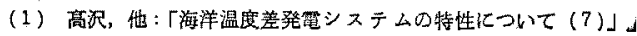
昭 57 電気学会全大, No. 1082

(2) R. R. Rothfus \& C.P. Neuman: "The OTEC Program at Carnegie-Mellon University Heat Transfer Research and Power Cycle Transient Modeling", 4th OTEC Conference New Orleans (1977)

(3) W. L. Owens: "OTEC Plant Response and Control Analysis", ASME J. of Solar Energy, 104, 208 (1982)

(4) 高沢・村田・酉山・䇻川!「海洋温度差発䉓シミニレータ」, 電気学会新・省エネルギー研資, ESC-84-13 (1984)

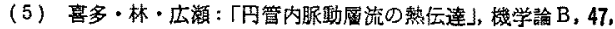
1080 (昭 56)

（6）機械学会：伝热工学望料 (改訂第 2版)

(7) T. Kajikawa, et al.: "Heat Transfer Performance of Metal Fiber Sintered Surfaces", Heat Transfer Engineering, 4, 57 (1983)

（8）嘉納：「雷みつき牫差法による分布系熱交換器の近似」, 計測 自動制部学会踰文集，12，632 (昭 51) 